\title{
On the Structure of the Political Party System in Indian States, 1957 - 2018
}

John Stephen Ferris ( $\nabla$ steve.ferris@carleton.ca )

Carleton University https://orcid.org/0000-0002-2801-9526

Bharatee Bhusana Dash

Xavier University

\section{Research Article}

Keywords: number of political parties, ENP, Indian states, entry and exit of political parties, BIMAROU and Non-BIMAROU states, fixed effects poisson panel estimation

Posted Date: June 9th, 2021

DOI: https://doi.org/10.21203/rs.3.rs-599921/v1

License: (1) This work is licensed under a Creative Commons Attribution 4.0 International License. Read Full License 
On the Structure of the Political Party System in Indian States, 1957 - 2018

\author{
by \\ J. Stephen Ferris* \\ (steve.ferris@carleton.ca) \\ Department of Economics, Carleton University, Ottawa, K1S 5B6 Canada \\ and \\ Bharatee Bhusana Dash \\ (bharatee.dash@gmail.com) \\ School of Economics, Xavier University, Bhubaneswar, India
}

June 6, 2021

\begin{abstract}
What accounts for the large and ever-changing number of political parties that contest Indian state elections? In this paper we test an equilibrium model of political parties where the number of parties depend on the average size of state constituencies, the heterogeneity of the state's electorate, state per capita income as well as constitutional and legislative rules that directly affect party numbers. Extending the analysis to consider the effects on entry and exits highlights those factors that have affected party turnover instead of or in addition to changing aggregate party numbers. Comparison of the effects on numbers with those on the effective number of parties (ENP) suggests that the model explains variations in the number of smaller sized parties that are a more transitory part of the electoral process. Whether this implies that the model is more applicable to the lesser developed Indian states is examined by re-testing the model against a subdivision of states that differ by their stage of development. While most variables work in the same way, increases in the proportion of reserved seats have decreased both party numbers and ENP in lower income states, with the opposite occurring in higher income states. The effect of state partition has been to decrease party vote fragmentation more than party numbers.
\end{abstract}

JEL Code: D72, D73, P16, H70

Key words: number of political parties, ENP, Indian states, entry and exit of political parties, BIMAROU and Non-BIMAROU states, fixed effects poisson panel estimation

* corresponding author 


\section{Introduction}

In this paper we model the changing structure of political party equilibrium and test for its predicted effects on the number, entry, exit and turnover of political parties across a subset of major Indian states since Independence. ${ }^{1}$ In general, new parties form to promote parts of the political spectrum not represented by existing parties (Meyer and Miller, 2015) or to break from existing parties whose platforms, leadership or regional representation are insufficiently representative of sub-group aspirations (Brancati, 2008; Lago and Martinez, 2011; Larose, 2017). The dimensionality of the issue space relative to the set of policies that any political party can hold means that it is unlikely that existing parties will generate the policy mix desired by all groupings within the electorate. In themselves, new parties are valued because they bring different ideas and new policies to the electorate and because of the threat this poses to established parties. They help ensure the responsiveness of the political process to the evolving wishes of the electorate (Aldrich, 1995; Mulligan and Tsui, 2015). What is more difficult to explain, however, is why an unsatisfied group chooses to pursue its political and economic goals outside of the structure of existing political parties, particularly when the likelihood of success diminishes with the number of established competitors. With the arrival of new ideas, the resurgence of older grievances, the arrival of new political agents and the always changing social economic landscape, groups wishing to promote change face the choice of merging their proposals and policies within the existing political structure or starting their own party based on these ideas. This choice will in turn be a function of the rules governing entry/exit, the receptivity of the electorate and established parties and the attention they can bring to the proposed cause versus the cost and likelihood of success as a new party dedicated to these ideas. In all these dimensions India exhibits interesting differences that can contribute to an explanation of its particular structure.

India, like Canada, has a political party structure that does not conform to Duverger's lawthe dictum that in a state with a first-past-the-post voting rule, the number of political parties

\footnotetext{
${ }^{1}$ The 14 states included in our analysis are: Andhra Pradesh, Bihar, Gujarat, Haryana, Karnataka, Kerala, Madhya Pradesh, Maharashtra, Odisha, Punjab, Rajasthan, Tamil Nadu, Uttar Pradesh, and West Bengal. Although Assam has held elections since 1951, its division in the 1960s and 1970s resulted in variations in the number of electoral constituencies and instability in the party system over the first three decades. In Jammu and Kashmir elections are held every 6 years as opposed to 5 years, and are often held amid heavy security, usually with low voter turnout. We have therefore omitted these states from our sample.
} 
will converge on 2. Even at the constituency level, according to Diwakar (2007), "there is no unequivocal support for it" (p. 557). 3,4 Explanations for India's 'exceptionalism' are many and include Chhibber and Kolman's (1998) argument that the number of parties depends upon the distribution of power between the central and state governments, with greater centralization decreasing the incentive to aggregate parties across states and encouraging the growth of local and regional parties. Others have pointed to the complexity of social cleavages across India (Chhibber and Petrocik, 1989; Yadav and Palshikar, 2003), the presence of a strong centrally positioned party (Congress) that encompassed the median voter (Riker, 1982, p. 271) and the importance of electoral institutions, such as the anti-defection rule (Nikolenyi, 2008). In this paper we re-examine India's structure of political parties from a broader public choice perspective, arguing that a number of complementary political and economic and institutional influences go into the determination of an equilibrium party structure and test these hypotheses empirically.

Much of the empirical work on political party structures has used cross country analysis (Hamel and Robertson, 1985; Hug, 2001; Travits, 2006; Brancati, 2008; Nishikawa, 2010; and Bolleyer, 2011). Here persistent cross-country differences in social cleavages and electoral institutional practices have been used to explain the variation that exists in the number of parties and/or rate of party entry/exit across countries. ${ }^{5}$ This has led to stylized facts such as democracies using proportional representation as opposed to first-past-the-post majority or plurality voting systems have characteristically larger numbers of active political parties (Harmel and Robertson, 1985). More recently, a specialized branch of cross-country analysis has focussed on post-communist emerging economies, seeking to isolate sources of political instability in entry-exit conditions (Sikk, 2005; Travits, 2008; Powell and Tucker, 2014). In this paper, however, we follow authors like Chhibber and Kollman (1998), Lago and Martinez (2011), Lucardie (2007), Chhibber, Jensenius and Suryanarayan (2014), Laroze (2017) and Ferris and Voia (2020) by applying the Cox (1997) analysis to party structure within a single

\footnotetext{
2 See Duverger (1954) and Grofman, Bowler and Blais (2009) for a contemporary reassessment.

${ }^{3}$ Diwakar (2007) studied Duverger's prediction at the national level. State constituencies are much smaller than national counterparts - on an average, 6 to 7 state electoral constituencies form one national electoral constituency. Dash et al. (2019) have shown that Duverger's prediction is violated even at the state level.

${ }^{4}$ Note that it is not unusual for an Indian state to feature more than 100 parties in an election. See the Data Appendix, Table A1, for descriptive statics.

${ }^{5}$ See Ordeshook and Shvetsova (1994), Amorim-Neto and Cox (1997) and Jones (2004) on the debate over institutions versus cleavages as the source of party fragmentation.
} 
country, in our case India, one that has a Constitution and electoral system that has remained fundamentally unchanged since Independence. Facing a common parliamentary setting for party formation and electoral participation, widespread differences in demographic, social, economic circumstances across states can be combined with specific Indian innovations in electoral rules and conventions to explain variations in the benefits and costs of party participation. By choosing Indian states, we can supplement the electoral data from the relatively short duration of India's democracy (1952-present) with a panel of state economic and political data. Our data set includes 14 of the largest Indian states and covers most of the 194 state elections that were held in these 14 states between 1957 and $2018 .^{6}$

The paper is organized as follows. Section 2 presents a rational choice model that predicts the changing structure of political party equilibrium and its implications for party entry and exit. Section 3 discusses the measurable proxies used to explain the structure of political party equilibrium, entry and exit decisions of parties and the empirical strategy that becomes our basis of testing the model's predications on Indian states. ${ }^{7}$ In section 4 we discuss the results and find the suggestion that the model is more applicable to variations in smaller sized political parties and exhibits greater sensitivity to factors associated with development. Section 5 examines the robustness of these implications by considering the extent to which our general findings apply equally to BIMAROU versus non-BIMAROU states - states grouped by significant differences in their stage of development. An important finding is that affirmative action, in terms of the reserving proportions of assembly seats for disadvantage group representatives, works differently. The final section concludes by summarizing our major findings.

\section{An Equilibrium Model of Party Structure with its Implications for Party Entry and Exit}

Cox (1997) provides the methodology used most often to explain the entry of new parties and, implicitly, the number of political parties that will arise in a stable political equilibrium. ${ }^{8}$ In his approach new parties form and enter the electoral arena when the benefits a new party can expect to receive from its electoral support exceed the costs of setting up the party and

\footnotetext{
${ }^{6}$ Incomplete coverage and omissions in the data result in 183 elections comprising the final data set.

${ }^{7}$ The data for this paper will be made available in Dataverse where it is titled 'Replication Data for the structure of political parties in Indian States'.

${ }^{8}$ See Miazzo, Moser and Scheiner (2018) for establishing the applicability of heterogeneity concerns for countries operating under first-past-the-post election rules.
} 
contesting an election. Party formation and entry will then continue until the party specific benefits of electoral participation fall into line with common entry costs. Once this equilibrium has been reached, entry and exit will follow from changes in the model's underlying determinants. Variables that proxy participation benefits, entry costs and the likelihood of achieving threshold political support are then used to test the predictions of the entry/exit hypotheses. This forms the conceptual basis of the empirical test described below.

More formally, a potential party $i$ in state $j$ at an election in time period $t$ will register as an entrant into the electoral process if the net benefit of entry exceeds the expected cost of entry, that is, if

$\operatorname{Prob}\left(\right.$ successful entry, $\left.N_{j-1}\right) \times$ Present Value of the expected benefits of participation $>$ Party setup costs + Present Value of expected participation costs,

where $N_{j t-1}$ represents the number of parties in state $j$ that are continuing from the previous election held in time period $t-1$. With the likelihood of success falling as the number of parties participating in the election increases, the entry of new parties will stop when the expected net benefit falls to zero. If in each election there is a flow of potential party entrants for whom the value of participating and probability of success differ, the existence of similar setup and participation costs will divide the number of potential entrants into two sets where the marginal entrant will be the one whose expected benefit just exceeds its expected costs. The number of entrants plus the number of continuing parties then determines a temporary equilibrium number of political parties participating in the election at time period $t$. It follows that a change in any of the underlying factors that increases the value or likelihood of a new party's electoral success and/or decreases the cost of participation will increase the expected number of parties entering and hence the equilibrium number of parties.

Once a party has entered the electoral arena, the continuation decision involves an optimal stopping rule. ${ }^{9}$ That is, an existing party will continue to participate in elections as long as the expected benefit of continuing exceeds the cost of participating in an additional election. Hence the optimal stopping point is to exit when

\footnotetext{
${ }^{9}$ See Ferris and Voia (2020) for the application of such a stopping rule to party exit and party lifespans in Canada.
} 
Marginal Benefit from continuing - the period cost of continued participation $<0$.

Note that the exit decision differs from the entry decision not only in the sense that perception of the benefit/cost of further participation may be more fully clarified after entry but also because the entry decision involves an additional set of once-and-for-all costs associated with party set up and registration. ${ }^{10}$ Once an entrant has entered, setup costs are sunk and this implies that parties considering continuation face a lower participation cost than entrants. This asymmetry implies that continued electoral presence can be supported even if the benefits of participation are found to be somewhat lower than those that motivated initial entry. $^{11}$

To operationalize these decision rules, we need to identify a set of exogenous factors whose levels explain the structure of political party equilibrium and whose changes can alter the probability of electoral success, the benefit of continued party participation, setup and/or continuation costs. Typically, the perceived benefit of electoral participation is private to the party and hence externally unobservable. This implies that a test of the theory requires finding a set of observable exogenous variables that span our 14 states and 61 years that provide measures of the other three components. In what follows we discuss these measurable proxies in terms of four broad categories: the size and heterogeneity of the electorate, the rules and conventions that have affected party entry and/or exit, the cost of entering relative to continuing in the electoral process, and the role of economic circumstance.

\section{Operationalizing the Model and Specifying the Tests}

\subsection{Variables of interest}

\footnotetext{
${ }^{10}$ The registration cost of setting up a political party in India is minimal (resulting in over 1600 political parties). Registration requires: a payment of non-refundable 10,000 Rupees (\$140.40 US), support of at least 100 recorded members with affidavits of stamp paper of at least 2 rupees, registration of the party's constitution and current operating officers and the annual audit party funds. Amended Guidelines for Party Registration, online at https://eci.gov.in/candidate-political-parties/political-parties-registration/. This does not imply that the setup time and personal expenditure costs to party members are not substantial.

${ }^{11}$ See Forand and Maheshri (2015) and Ferris, Olmstead and Winer (2018) for an analysis of how this cost differential implies an asymmetric short run adjustment process about a longer run equilibrium.
} 
We begin with the size and heterogeneity of the electorate as key determinants of the state's demand for political parties. ${ }^{12}$ In general, the larger is the pool of voters relative to the minimum scale of voter support needed to justify party participation, the larger will be the number of political parties that can survive in equilibrium. For any given degree of voter heterogeneity, a larger voter base will support a larger number of distinct voter interests. Similarly, for any given size, the more diffuse are the interests and aspirations of voters, the larger will be the number of parties that arise to reflect those interests. In our case this implies that elections in states with larger sized voting constituencies and more heterogeneous constituents would be expected to support a larger number of political parties. Changes in these dimensions then create opportunities for new political parties to enter and challenge the incumbents for electoral support.

When the Constitution of India came into effect in 1950, voting rights were extended to all Indian citizens. Hence with voter registration not an additional concern and holding heterogeneity constant, the average size of the voting constituency is expected to be a key determinant of the number of viable political parties. Our analysis then predicts that the larger is the number of registered voters in each constituency (constituency density), the larger will be the number of political parties that can be supported. Similarly, changes in this variable are predicted to be positively related to the entry of new parties and negatively related to exit.

We turn next to indexes of state heterogeneity as a measure of the demand for separate parties. Here caste identity is thought to represent the single most important factor in voters' electoral choice and its centrality in Indian politics is often expressed in the phrase 'Indians vote their caste while casting their vote'.$^{13}$ While Indian states differ widely in their caste, class and ethnic composition, special election rules have been adopted to compensate for disadvantages arising across these groups. For example, in each state assembly a certain proportion of seats are reserved for two disadvantaged minority groups: scheduled castes

\footnotetext{
${ }^{12}$ See also Taagepera and Grofman (1985), Hug (2000), Clark and Golder (2006), Spoon and West (2015), Kapoor and Magesan (2018), and Ferris and Voia (2020) who highlight scale and diversity.

${ }^{13}$ See Jaffrelot (2012) on caste alliances with political parties in India and Church (1984) and Harriss (1999) for a discussion of the caste and class centric politics of Indian states.
} 
(SCs) and scheduled tribes (STs) (seat reservation). ${ }^{14}$ In these reserved constituencies, only candidates who belong to the reserved group can contest the election, while the entire electorate votes, irrespective of their social identity. In many states, however, the proportion of reserved seats is quite large, in our sample varying from a low of 9 percent of the seats in Kerala in 1970 to 40 percent of the seats in Odisha in 1971 with an overall state average of 22 percent. The proportion of reserved seats in the legislature is also highly correlated (and inversely so) with an index of religious fragmentation $(\rho=-0.54)$, implying that states with high concentrations of scheduled castes and tribes are not as religiously diverse as others (religious frag). ${ }^{15}$ Because groups receiving legislated affirmative action tend to support a small number of representative parties, a higher proportion of reserved seats will reduce the proportion of seats available for parties representing the general electorate. The expectation is then that seat reservation will be inversely related to the number of political parties that will arise in equilibrium. ${ }^{16}$ Similarly increases (decreases) in that proportion are expected to lead to the exit (entry) of parties.

To capture other forms of heterogeneity among voters more generally, we used two additional measures of voter diversity: old, the percentage of the population older than 60 and, literacy, the percentage of the population that is judged to be literate. An increase in the percentage of older voters is expected to lead to greater conservatism in the electorate and imply greater partisan attachment to established parties. ${ }^{17}$ This is expected to reduce the

\footnotetext{
14 The post-independence Indian constitution created a political reservation provision for disadvantaged minority groups. Religion, however, is not used as a basis for political reservation. The percentage of seats reserved for SCs and STs in both federal and state legislatures is based on the population shares of SCs and STs. The number of reserved seats and their share in total seats in a state changes when a state is bifurcated, a new set of delimitation commission's recommendations are implemented, or when the definition of SC or ST changes. Definition of SCs and STs were made uniform within a state with the implementation of the Scheduled Caste and Scheduled Tribe Orders Act of 1976 in 1977. For many states seat reservation stays constant across multiple elections. See Chin and Prakash (2011) for a more detailed discussion.

${ }^{15}$ To measure religious diversity, we used a Herfindahl index of denominational affiliation, interpolated between censuses and averaged over the previous governing period. Because of its high correlation with seat reservation and because more political parties use caste rather than religion to build party support, we used seat reservation rather than religious frag in our regression analysis.

${ }^{16}$ Comparing the electoral outcomes in constituencies with reserved versus non-reserved seats, Auerbach and Ziegfeld (2020) found the crowding out of candidates and the focusing of competition on the major parties minor parties in constituencies with reserved seats while Mori and Kurosaki (2011) found voter turnout lower in reserved constituencies. Focusing only on reserved SC constituencies, Jensenius (2017) found lower numbers of candidates contesting elections, higher vote margins of victory, and lower turnout rates compared to unreserved ones. These studies focus on the impact of electoral reservation at the constituency level, we study reservation's effects on party structure at the assembly level.

${ }^{17}$ See Dassonneville (2017, p.137).
} 
number of political parties and reduce the scope for entrants. On the other hand, an increase in literacy has been associated with larger voter turnout which in turn broadens the electorate available to additional parties (Kaplan and Venezky, 1994). ${ }^{18}$

To capture the role of economic circumstance on political party numbers, we use real per capita income across Indian states. Hence if we can assume that the demand for political diversity is a normal good, the demand for new parties offering different policy programs should rise with state incomes. Other things equal, the number of political parties should be larger in states with higher levels of income and rise through time in all states as state income levels rise. It follows that state real GDP per capita, srgdppc, should be associated positively with higher numbers of political parties. Similarly, from the entrant's perspective, the cost of raising funds will be lower when times are good while the cost of maintaining relatively unsuccessful political activity will be increasingly difficult when times are bad. We test for the effects on entry and exit by using the annual average growth rates of per capita income calculated over the governing interval of the incumbent government.

We turn next to consider the significance of governance rules and conventions that may affect the number of parties by changing the incentives for party entry and/or exit. Here the $52^{\text {nd }}$ Constitutional Amendment Act of 1985 stands out. Introduced as a way of countering the extraordinary degree of post-election party switching by legislators, ${ }^{19}$ the anti-defection law not only prohibited party defections, but also disqualified a legislator if that legislator voted (or even abstained from voting) contrary to any direction issued by his/her political party (Sethia, 2019, p.28). Somewhat ironically, by suppressing internal party dissent the antidefection law is thought to have spurred the growth of new political parties by requiring internal factions to form an alternative party between elections to allow dissenting voices to be heard. To capture the effect of anti-defection law, we use a dummy variable, antidefection, that takes the value of 1 in all elections following 1985, 0 otherwise.

\footnotetext{
${ }^{18}$ In earlier work we also used urbanization as a heterogeneity measure because of its wide variation across Indian states and over time. However, there is no current consensus on how the urban-rural split is expected to affect electoral participation [for recent work Stockemer and Blais (2019) and McAllister and Muller (2018)] and urbanization was found to be insignificant in all forms of our test.

${ }^{19}$ Between 1967 and 1983, there had been more than 2700 cases of party defections, which brought down over 16 state Governments. See Sethia (2019, p.25) who acknowledges Stanley A Kochanek, 'Mrs. Gandhi's Pyramid: The New Congress' in Zoya Hasan (ed.), Parties and Party Politics in India (Oxford University Press 2004, p78).
} 
An election convention that affects the effectiveness of a political party is party recognition status. That is, in addition to having to be registered as a political party to run in an election, a political party can qualify to be 'recognized' as either a State or a National party if the party meets certain minimum vote criteria. ${ }^{20}$ The biggest advantage of being recognized as a State (National) Party is the receipt of a reserved symbol for exclusive use within the state (nation). This facilitates party recognition by all voters and aids candidate coordination by allowing all contesting candidates from that party to be linked by using the same symbol throughout the state. ${ }^{21}$ There are other advantages received by recognized parties such as subsidized land for party offices, free air time on India's autonomous public service broadcaster, the supply of electoral roll copies free of cost during elections and other incidentals. By lowering the cost of party organization, the introduction of party recognition status in the elections following 1968 is expected to increase the number of viable political parties in state elections. To test this hypothesis, we use a dummy variable, party recognition, that takes the value of 1 for all elections following 1968 and 0 otherwise.

In common with other countries, India requires candidates for office to pay a deposit before running for office that is returned only if a candidate receives more than a minimum share of the constituency vote (in India's case 1/6 of the vote). In 1951 this was set at 500 rupees for general candidates and 250 rupees for schedules caste or tribe candidates and remained at that level unchanged for 50 years. As Kapoor and Magesan (2018, p. 678) write, "[b]y 1996, the deposit had eroded to almost nothing in real terms, and from a pecuniary standpoint, candidate entry was effectively free". The low cost of candidate entry led to a massive proliferation of candidates (Bhattacharya and Mitra, 2014), encouraging 'frivolous' candidacy for reasons such as parties running dummy candidates to steal votes from opponents (Kapoor and Magesan (2018, p. 691)) and the promotion of name recognition within a district.

\footnotetext{
${ }^{20}$ The election Symbols Order of 1968 sets any one of five conditions that need to be satisfied for State Party status: secure at least $6 \%$ of the valid vote and win at least 2 seats in a (Vidhan Sabha) Assembly Election; secure at least 6 percent of the valid vote and win at least 1 seats in a (Lok Sabha) General Election; win at least 3 percent of the seats or at least 3 seats, whichever is more, in an Assembly Election; win at least 1 out of every 25 seats from a state in a General Election; or secure at least 8 percent of the total valid vote in an Assembly or a General Election. There are a similar set of national conditions set for recognition as a National party.

${ }^{21}$ As of 2016 there were 7 National parties and more than 50 State parties versus more than 2300 registered parties that were unrecognized.
} 
To counter this effect on the number of independent candidates, the Electoral Commission in 1996 increased sharply the deposit requirement for general and special candidates to 10,000 and 5000 rupees respectively. While the more than tenfold deposit increase did have a dramatic effect in decreasing the number of independent candidates running, the effect on the number of parties and the entry and exit of parties has not been assessed. However, the higher cost of running multiple candidates raises the cost of maintaining a party that consistently receives less than a $1 / 6$ of the vote and so would discourage the proliferation of minor parties. To account for the higher cost of party electoral participation, we first construct a dummy variable, deposit increase, equaling 1 in each election following 1996, zero otherwise. Then because the new higher deposit level was kept at this level across time, we allow the real value of the increase to depreciate through time (due to inflation) and use the variable adj_deposit increase. ${ }^{22}$

The final institutional change we consider for its effect on the number of political parties is the passing of the $61^{\text {st }}$ amendment to the Indian Constitution in 1989 that reduced the voting age from 21 to 18 years (voting age). This broadening of the franchise had two effects both of which would be expected to increase the demand for more political parties. First, the broadening of the franchise discretely increased the number of voters in each constituency by roughly 20 percent (28\% in Gujarat, $23 \%$ in Kerala and $26.5 \%$ in Madhya Pradesh). Second, the entering voters were all young, increasing the heterogeneity of the voting (Dassonneville, 2017). The prediction is that voting age would be associated with a permanent increase in the number of political parties and a one-time increase in the entry of new parties into the political arena in the first election following 1989.

As has been noted by many others, India's party structure has also been profoundly affected by the special conditions that surround its origin and two special events that are expected to have perturbed the equilibrium number of parties and the time pattern of party entry and exit. The first relates to the central role played by the Indian National Congress party, commonly known as the Congress party, in the formation and early governance of modern India. Particularly in the first few decades following independence, the Congress party

\footnotetext{
${ }^{22}$ We allow the real value of the deposit to fall by half by 2018 .
} 
dominated elections both at the center and in majority of states. ${ }^{23}$ In the mid-1970s the Congress party began to experience challenges to its dominance both at the center and across some states and, over the next few decades, its strength gradually weakened. By the 1990s, the hegemony of the Congress party had ended and India had become a full-fledged multiparty system. ${ }^{24}$ We use Congress party's vote share in an election, congress vote, to represent its strength and expect it to have a negative association with the number of parties. Similarly, increase in vote share of the Congress party is expected to be negatively related to the entry of new parties and positively related to exit.

The National Emergency, declared by Prime Minister Indira Gandhi and lasting from 25th June 1975 until 21st March 1977, has had a significant impact on Indian politics, at both national and state levels. Its biggest impact, however, was on the elections that immediately followed its withdrawal. The imposition of emergency made the Congress Party extremely unpopular throughout India leading to a group of the major political parties forming a coalition, formally known as the Janata Party, with the sole objective of defeating the Congress Party. The coalition succeeded in defeating the Congress Party at the national level and in most of the states in the elections. The first elections held after the lifting of emergency had anomalous electoral outcomes at the state level (see, for example, Dash et al (2019) for political competitiveness and Dash and Ferris (2020) for electoral volatility). We have used a binary variable, emergency, taking the value of 1 for these elections alone to account for emergency's impact on the number of parties. Given that most of the parties opposing the Congress Party had forged a pre-election coalition for the first elections after the emergency, we expect the number of contesting parties in these elections to be smaller, resulting in the appearance of a decrease in entry and increase in exit in the number of parties.

Finally, in 2000, three new states--Jharkhand, Chhattisgarh, and Uttarakhand-were carved out of three of the largest Indian states-Bihar, Madhya Pradesh, and Uttar Pradesh. ${ }^{25}$ Because our dataset does not include these states, the process of state creation impacts our

\footnotetext{
${ }^{23}$ Kothari (1970) termed this as the 'congress system'. See also Chhibber and Verma (2018) on the role of Congress.

${ }^{24}$ Yadav and Palshikar (2003) provide a detailed account of party system evolution and electoral politics in Indian states.

${ }^{25}$ In 2014 another new state named Telangana was created out of Andhra Pradesh. The process of state creation, however, was completed months after the 2014 assembly election. Since the 2014 election was held in the undivided state of Andhra Pradesh, the creation of Telangana state does not affect our dataset.
} 
data through a discrete change in the size and composition of the constituencies of the newly partitioned states. If state bifurcation produces a more homogenous electorate in ways unaccounted for by our other variables, a lesser number of parties should be seen in the post state creation elections, and vice versa if heterogeneity increases. A dummy variable, state creation, taking the value 1 for the post state creation elections of these three large states ( 0 otherwise) is introduced to account for this effect. We have no prior expectation for the sign of this coefficient.

\subsection{Model Specification}

Because the number of parties participating in an election is a discrete number, the analysis that follows uses a fixed effects Poisson count regression model to test for the significance of the proposed set of political, institutional and economic conditions expected to explain the structure of political parties across Indian states. ${ }^{26}$ The equation can be written as

$$
\begin{aligned}
& E\left(N_{j t}\right)=\alpha_{1} \text { constituency density }_{j t}+\alpha_{2} \text { seat reservation }_{j t}+\alpha_{3} \text { old }_{j t}+\alpha_{4} \text { literacy }_{j t}+ \\
& \alpha_{5} \text { srgdppc }_{j t}+\alpha_{6} \text { party recognition }_{t}+\alpha_{7} \text { anti defection }_{t}+\alpha_{8} \text { adj }_{\text {deposit }_{\text {increase }}}+ \\
& \alpha_{9} \text { voting age }_{t}+\alpha_{10} \text { congress vote }_{j t}+\alpha_{11} \text { emergency }_{j t}+\alpha_{12} \text { state creation }_{j t}+\beta_{j}+ \\
& \delta_{t}+\varepsilon_{j t}
\end{aligned}
$$

where $E\left(N_{j t}\right)$ is the expected number of parties in state $j$ at election date $t$. The coefficients $\alpha_{1}, \alpha_{4}, \alpha_{5}, \alpha_{6}, \alpha_{7}$, and $\alpha_{9}$ are expected to be positive while $\alpha_{2}, \alpha_{3}, \alpha_{8}, \alpha_{10}$ and $\alpha_{11}$ are expected to be negative. We have no a priori expectation for the sign of $\alpha_{12}$. $\beta_{j}$ represents state fixed effects and accounts for all state-specific time-invariant differences in the number of parties. Usually, a time dummy would be used to control for time-specific national events that affect all the state elections arising in that election year. In our case, however, election years are not synchronized across states so that use of the large number of election years in our panel (51) would severely reduce our degrees of freedom. ${ }^{27}$ Therefore, because governments in India are elected for a maximum tenure of 5 years and assuming that the environment does not change drastically across a

\footnotetext{
${ }^{26}$ Note that in a poisson 'count' regression the coefficient estimates are interpreted as the difference in the logs of the predicted variable for a unit change in the predictor variable, given that the other predictor variables in the model are held constant.

${ }^{27}$ Number of elections varies between 12 in Maharashtra and Haryana to 16 in Uttar Pradesh. One reason for this difference is that the starting election years for all state in our sample is not the same- the state of Bombay was divided into Gujarat and Maharashtra in 1960 and the first elections in these states were held in 1962, and Haryana was carved out of Punjab in 1966 and the first election in Haryana was held in 1967.
} 
5-year cycle, we have divided our sample period into 5-year cycles starting from 1955 and have introduced dummy variables for each cycle. ${ }^{28}$ State elections held within a cycle (some states had more than one election) take the value $1 ; 0$ otherwise. $\delta_{t}$ in equation (3) represents these 5-year cycles. ${ }^{29} \varepsilon_{j t}$ is the random error term.

The fixed effects Poisson regression equation (3) is used to test the entry and exit decisions (together with their combination in turnover or churning) using the first differences of continuous explanatory variables together with the discrete changes reflecting changes in election rules and conventions.

\section{Results}

\subsection{The number of parties versus effective number of parties}

In Table 1 we present a set of fixed effects Poisson models to test the predicted role played by our two categories of determinants on the number of political parties present in our panel of Indian state elections. ${ }^{30}$ In the odd numbered columns (1), (3) and (5) the models use the proportion of reserved seats without distinguishing reservation type, whereas the even numbered columns (2), (4) and (6) disaggregate reserved seats by the proportion of seats allocated to SCs versus STs. The models also build in complexity: columns (1) and (2) focus on a model that uses only the size and demographic characteristics of the voter pool together with the level of state income per capita; columns (3) and (4) add the four institutional election rules together with the three special events specific to India's party structure. Columns (5) and (6) then re-run the full equation models of columns (3) and (4) on the effective number of political parties (ENP), where ENP weights the significance of each party by its vote share and is measured as the inverse of a Herfindahl index of party vote shares. ${ }^{31}$

\footnotetext{
${ }^{28}$ There is nothing special about the starting point used for the beginning our 5 -year cycles (1955). Changing the starting point by a year or two backward or forward does not change our results much. As an alternative to election cycle time dummies, we also used the state election number as a covariate in our model. This is done in Table $\mathrm{A} 3$ of the Appendix and shows similar results.

${ }^{29}$ Jensenius (2017) has used a similar approach.

${ }^{30}$ All poisson panel models use both fixed state and election (cycle) effects.

${ }^{31} \mathrm{ENP}_{\mathrm{j}}=\frac{1}{\sum v_{i j}^{2}}$, where $v_{i}$ is the vote share of each political party, $\mathrm{i}=1,2, \ldots \mathrm{N}$, in state $\mathrm{j}$. We follow Dash et al. (2019) by defining a political party as any registered party in the top ten vote receiving parties over three successive elections or receives more than 8 percent of the vote in any one election (all other parties and individual candidates included in a composite grouping, other). Winer et al (2019) use electoral data up to 2013 and the data is available at https://dataverse.scholarsportal.info/dataset.xhtml?persistentld=doi:10.5683/SP2/N3GJR4. We have updated that dataset for the elections up to 2018.
} 
Unlike the number of parties, which is a positive integer, ENP can be any positive real number. Before applying Poisson estimator, we have rounded off ENP numbers to their closest integer. A comparison of the results from columns (3) and (4) versus (5) and (6) provide some of our most interesting results.

From an overall perspective, the models explaining the number of political parties in columns (1) and (3) variables provide a much better fit with the data than the effective number of parties in column (5). Of the 16 coefficient estimates with a predicted sign, all but one conform to expectation with 12 of these coefficient estimates significantly different from zero (at $10 \%$ or lower). The variable with a sign contrary to expectation (Congress vote) turns out to be statistically insignificant. In contrast only four of the 11 signed coefficient estimates in the ENP case of column (5) are significantly different from zero. The ability of the model to explain the number but not the effective number of parties suggests that the models of columns (1) and (3) are capturing changes in the number of smaller political parties whose presence has only a marginal influence on their larger sized rivals. ${ }^{32}$ This can be seen most clearly in the case of voting age where the decrease in voting age is associated with increase in the number of parties but a significant decrease rather than increase in ENP. The increase in the size of the Log likelihood statistic as we transition from (1) to (3) confirms that the institutional and political variables added to the model has significantly increased the explanatory power of the number model. This also implies that both 'cleavages' and institutional features play an important role in explaining party numbers in these Indian states. $^{33}$

--inset Table 1 about here--

Turning to the individual predictions, a larger average number of voters in each constituency, constituency density, is associated with a significantly larger number of parties (as expected)

\footnotetext{
${ }^{32}$ Log likelihood statistic is a better measure of the goodness of fit test. Though a higher Log likelihood statistic for ENP might suggest that the ENP model has a better fit, the statistics are not directly comparable as the scales of the dependent variables are different (see the data appendix, Table A1, for the descriptive statistics).

${ }^{33}$ Although the poisson form of the test is more appropriate for the discreteness of party numbers, we estimated a linear version of the model in column (3) for comparison. The linear version of the model better suits the continuity of positive real numbers in ENP. The linear results closely resemble the Poisson results of Table 1 illustrating that our baseline results are robust to an alternative estimator (see the appendix, Table A2, for detail). To check the robustness of Table 1's results, we have estimated results using an alternative strategy: state election years is used as an explanatory variable in our models in place of the election cycle time dummies. These results too closely resemble the results of Table 1 (see the appendix, Table A3, for the results).
} 
but producing no significant impact on the effective number of political parties. This is consistent with a larger and more heterogeneous voting pool attracting an inflow of smaller fringe parties that make no discernable impact on the vote shares received by the larger state parties.

As expected, an increase in the proportion of reserved seats, seat reservation (All), is associated with a decrease in the both the number and the effective number of state parties, but with coefficient estimates that are statistically insignificant. ${ }^{34}$ In work done on reservation status in India, however, researchers have found significant differences between the two groups with reservation status resulting in different levels of electoral participation and policy outcomes (see Pande, 2003; Chin and Prakash, 2011; and Mori and Kurosaki (2011). The two social groups differ in that STs are relatively homogenous groups that live together in geographic isolation, whereas SCs are more socially heterogenous with greater fragmentation and wider geographic scattering. ${ }^{35}$ After dividing aggregate reserved seat shares into reserved seat shares for SCs, seat reservation (SC), and STs, seat reservation (ST), and re-estimating the models of columns (1), (3), and (5) as the models in columns (2), (4), and (6) respectively, the increases in the Log likelihood statistics of these models suggest that using seat reservations for SCs and STs separately produces a better fit with the data. The re-estimated results then show that while an increase in both reservation variables is associated with a decrease in the number of both parties and ENP, only for SCs does the number of parties decrease significantly. This suggests that despite being geographically scattered and facing greater social heterogeneity, caste identification allows the SCs population to better use its reserved status within the structure of the major parties. Cultural identity allows the SCs to better mobilize diffuse voters from all cross-sections of the society for a number of political purposes that benefit the group, hampering the proliferation of smaller and fringe parties who face organizational and other institutional constraints. This is unlike the STs whose geographic and social concentration tends to concentrate political focus on issues such as rural poverty (Chin and Prakash, 2011). At a broader level, these results complement the existing studies of Mori and Kurosaki (2011) and Auerbach and Ziegfeld (2020) who have

\footnotetext{
${ }^{34}$ Note that because of the high collinearity between seat reservation and religion frag, religion frag was dropped from the analysis.

${ }^{35} \mathrm{SCs}$ have both a higher average proportion of assembly seats (.153 versus .07) with smaller dispersion across states (.052 versus .077) than do STs.
} 
shown that the electoral reservation system for SCs and STs has affected political outcomes differently.

Our two more general heterogeneity measures, old and literacy, produce coefficient estimates consistent with expectation and both are found to be significantly different from zero. An increase in the proportion of the population over sixty is associated with a smaller number of political parties and an increase in literacy (through higher voter turnout) to a larger number of political parties. Neither is associated significantly with ENP. The measured effect of literacy is weakened when the institutional and other political covariates are added into the model while measured impact of old is increased.

The hypothesis that the demand for political diversity through a larger number of political parties rises with economic wellbeing is strongly supported by the data. The data is consistent with an increase in real state GDP per capita, srgdppc, increasing the number of parties (and works better with the full model) but not with the effective number of parties. This is again suggestive that in India, higher incomes in a state support a wider range of programs and specialized policies embodied in additional parties without significantly undermining the vote shares received by larger state and national parties.

Turning to Constitutional amendments and changes in electoral rules adopted by India, we find in columns (3) and (4) considerable support for the expected effects produced by institutional change. In particular, the adoption of party recognition measures, the passing of anti-defection legislation and the lowering of the voting age are all found to have had a significant effect in increasing the number of political parties. Two of these institutional variables, party recognition and voting age, also have had significance effects on ENP - the former increasing party fragmentation, the later decreasing fragmentation. The significance of anti-defection legislation on party numbers but not ENP is strongly supportive of the hypothesis that this law was successful in increasing electoral consistency and candidate accountability by reducing party defections but at the cost of proliferating the number of smaller parties. Finally, unlike the results found for political candidates by both Bhattacharya and Mitra (2014) and Kapoor and Magesan (2018), the more than tenfold increase in the candidate deposit fee in 1996 does not appear to have had any significant long run effect in decreasing either the number of parties or ENP. 
After accounting for the other determinants of party numbers, the strength of the Congress party, congress vote, was not found to have a significant effect on the proliferation of smaller political parties. However, the results in columns (5) and (6) find that falling Congress party vote shares are associated significantly with increases in party fragmentation through the rise of larger, more competitive state parties. This finding is then consistent with the story told by Yadav and Palshikar (2003) and others of the evolution of the party system in India from one of one-party dominance to a multi-party system as the dominance of the Congress party declines. The data also indicate that emergency, the first elections after the lifting of National emergency were unique. The grand coalition formed to defeat the Congress party was successful but at the expense of a significant increase in the concentration of the vote among a smaller number of major political parties.

Finally, the data indicates that the partitioning of Bihar, Madhya Pradesh and Uttar Pradesh is associated with a significant increase in the number parties in the affected states without there being a significant effect on the effective number of parties. The data is then consistent with the hypothesis that partitioning resulted in the removal of a more homogeneous block of voters such that the average remaining constituency became more heterogeneous resulting in a significant increase in the number of smaller political parties. For the full panel of 14 states, partitioning did not produce greater vote fragmentation among major parties. However, because state partition affected only a small number of somewhat distinctive states, we return to consider the effect of these partitions in section 5 where we form subgroupings of our panel of states by their level of development.

\subsection{Party Entry, Exit and Turnover}

While the number of political parties in the average Indian electoral constituency is often seen as exceptionally large, perhaps even more impressive is the number that enter and exit each election period. As the descriptive statistics in the Appendix indicate, an average of 16 new parties enter while 10 parties exit. In Table 2 we present the results of using our Poisson model to explain the entry, exit and turnover of political parties in Indian state elections. The model uses the first differences of the explanatory variables used in Table 1 columns (3) and (4) and once again allows for separate effect of SCs and STs in the even numbered columns. 
Note that all three models have considerable explanatory power as reflected in the large size and statistical significance of their $\chi^{2}$ values.

The results here are of interest not only in their own right but also for the insight they shed in how the overall results outlined in Table 1 have arisen. For example, in most of our cases the effect of a variable change on total party numbers arises primarily from the size and significance of the effect arising on entry or on exiting but usually not both. In many of these cases, the effects produced on entry and exit are complementary in which case the overall effect falls primarily on the number of parties. When the two effects work against each other, that is, when the coefficient estimates have the same sign, the net effect arises in the rate of party turnover with modified effects on total party numbers.

--insert Table 2 about here--

Increases in the percentage of the population that is older than 60 and in the Congress Party's vote share are cases where entry and exit change in complementary directions. An increase in $\mathbf{D}$ (old) is associated with reduced entry and raised exits and this results in the significant increase in party numbers shown in Table 1 , whereas a decrease in $\mathbf{D}$ (congress vote) is associated with a significant increase in party entry helping to explain the significant rise in party fragmentation (ENP) across time as shown in Table 1. Increases in the voting size of the electoral constituency, growth of real income over the electoral tenure, legislations of party recognition and anti-defection are complementary in the opposite direction, increasing entry and discouraging exit to explain the significant increase in total party numbers attributed to these variables in Table 1. Party entry and exist results of $\mathbf{D}$ (constituency density) and antidefection in Table 2 also produce significantly higher party turnover.

On the other hand, the discrete effects of voting age legislation, emergency, and state creation produce offsetting changes on total party numbers through increases in both party entry and exits. The emergency is associated with significant party exits while state creation is associated with significant party entry; the former producing a decline, the latter producing a rise in party numbers. Lowering the voting age has significantly increased both party entry and exits, with the stronger party entry effect resulting in the significant net increase in party numbers seen in Table 1. All three of these discrete measures are associated with a significant increase in party turnover. 
Increases in seat reservations (All, SCS, and STs), literacy and the adj_deposit increase produce offsetting changes on total party numbers by decreasing both party entry and exit. D(seat reservation (All)) and the adj_deposit increase affect neither entry nor exits significantly, nor does their combined effect produce any significant impact on party numbers or turnover. In the case of $\mathbf{D}($ seat reservation (SC)) and $\mathbf{D}$ (literacy), neither entry nor exit is significantly affected, but in combination their aggregate effect is sufficient to make the effect on party numbers significant (increases in seat reservation (SC) decreases numbers while greater literacy increases them). Finally, an increase in $\mathbf{D ( s e a t ~ r e s e r v a t i o n ~ ( S T ) ) ~ r e d u c e s ~ p a r t y ~}$ entry significantly, contributing to significant decline in turnover but not in party numbers. Perhaps most importantly, the differing results found for SC and ST assembly seat reservations reinforces our earlier findings (and by others in different electoral contexts) that political affirmative action works differently for these two minority groups. Considering them only in combination may hide insights that separate consideration may provide.

\section{Party Structure by Level of Development}

In a country the size of India, the average outcome across an all-state grouping can often mask important differences arising within. As we have seen, many of the factors influencing the number of parties appear to impact primarily the fringe of smaller parties and many of the heterogeneity indicators used in the model are variables often those associated with a country's stage of development (such as per capita income and literacy). It may then be insightful to consider whether the effects on party structure are concentrated among states at a lower level of development, particularly whether the constitutional and/or legislative changes have affected these states in different ways. In this section we consider the robustness of our findings by applying our model to states grouped by their stage of development.

When examining development differences across Indian states, an increasing number of studies have used the distinction between BIMAROU and non-BIMAROU states. ${ }^{36}$ The acronym BIMAROU, resembling the Hindi word bimar, meaning 'sick', is often used to characterize the state of development arising in the five poorest Indian states - (Bi)har,

\footnotetext{
${ }^{36}$ Recent studies using this distinction include Ghosh (2016) and Mishra and Mishra (2018) who focus on differences in growth rates among the BIMAROU and Non-BIMAROU states and Prakash et al (2019) who study differences in economic costs of electing criminally accused politicians.
} 
(Ma)dhya Pradesh, (R)ajasthan, (O)disha, and (U)ttar Pradesh. These five states typically lag the other nine in terms of their population's access to: public health, education, tap water, electricity and toilets and so on (in addition to per capita income). One example of where this distinction was found to be significant is a recent study by Winer et al. (2020) that finds that changes in political competitiveness lead to opposing changes in the private-public good composition of government state budgets, implying important differences in the impact of political competition across these groups. Here we ask whether our determinants of the number and effective number of political parties differ in their effect on BIMAROU states from those arising in the more developed states.

--insert Table 3 about here--

The full equation fixed effects Poisson model of column (4) in Table 1 (which treats SCs and STs reserved seats separately) was estimated for the BIMAROU and Non-BIMAROU subsamples and the results presented in columns (1) and (2) of Table 3. The same exercise was carried out for ENP with the results for the BIMAROU and Non-BIMAROU states presented in columns (3) and (4). While the separation of states by stage of development allows different interrelationships among model's covariates to better show through, one need to be cautious in interpreting the results of party numbers in the BIMAROU states of column (1) as the $\chi^{2}$ value turns out to be statistically insignificant, implying that all covariates are not jointly significant.

While variables such as srgdppc and the anti-defection legislation are found to be equally significant across the two state groupings, some forms of heterogeneity and some institutional factors are found to have produced a more significant effect on one of the state groupings. For example, the introduction of party recognition status is associated with a larger number of parties and greater vote fragmentation in both groups but has produced a significant effect on numbers only in the non-BIMAROU states. On the other hand, the rise of literacy among the electorates is associated with rise in both party numbers and ENP in both subgroupings, but its estimated effect is larger and significant only within the BIMAROU states.

In other cases, common heterogeneity and institutional effects on party numbers have affected the distribution of party sizes in BIMAROU and non-BIMAROU states differently. For 
example, constituency density, old and adj_deposit increase affect party numbers in both state groupings in the same direction but have had opposing effects on ENP and vote fragmentation. An increase in constituency density significantly increases party numbers in both BIMAROU and Non-BIMAROU states. But in non-BIMAROU states the increased numbers results in greater vote fragmentation while in BIMAROU states votes are more concentrated among parties. The aging of the state populations is associated with a decline in party numbers in both state groupings, but significantly so only for the BIMAROU states where the reduction is sufficient to significantly lower ENP and vote fragmentation among BIMAROU state parties. The expected negative effect on party numbers of the discrete rise in candidate deposit fees, adj_deposit increase, is only suggested by the data. However, ENP and fragmentation rise significantly in the BIMAROU states, whereas non-BIMAROU states are largely unaffected. Our final institutional change, the lowering of the minimum voting age, voting age, that was highly significant in the combined state case is now found to be individually insignificant when states are separated by their stage of development. The earlier found effect of lowering ENP is now found only for non-BIMAROU states.

It is with respect to reserved assembly seats that we find the largest and most significant difference. Affirmative political action in the form of reserving assembly seats for candidates from disadvantaged social groups resulted in a reduction in the number of political parties competing in the lesser developed BIMAROU states, producing a concentration of vote shares among more dominant parties. In non-BIMAROU states, however, the opposite has happened with greater proportions of reserved seats associated with more political parties and greater vote fragmentation (but not significantly so). In the BIMAROU states the results are driven by the STs whereas in the non-BIMAROU states the two groupings have responded similarly with the SC and ST coefficient estimates not statistically different.

While it appears that BIMAROU/non-BIMAROU distinction in Table 3 is the more fundamental reason for the significance of SCs versus STs found in Table 1, both results are likely to derive from the same common condition. That is, one significant difference between BIMAROU and non-BIMAROU states is that the average proportion of seats in the legislature reserved for SCs and STs in BIMAROU states is both large absolutely (0.29) and significantly larger (1.6 times) than the average proportion of reserved seats in non-BIMAROU states (0.19). In addition, while the proportions of SC seats in the two groups are comparable $(0.17$ in 
BIMAROU states and 0.15 in non-BIMAROU states), the proportions of ST seats are disproportionally concentrated in the BIMAROU states (0.12 in BIMAROU states and 0.04 in non-BIMAROU states). The presence of a higher combined share of disadvantaged groups, with closely matched SCS and STs population proportions, seems to have driven the party structure in BIMAROU states in a different direction compared to that in non-BIMAROU states. Given the ability to appeal to specific concentrated groups with specific group interests for electoral advantage, a further increase in the reserved proportion in BIMAROU states would place a more effective constraint on the legislative space available for non-reserve group oriented party alternatives, resulting in the crowding out of minor parties and the concentration of vote shares among a smaller set of dominant parties. ${ }^{37}$ In the non-BIMAROU states, the smaller proportion of special castes in the population encourages members of reserved groups under affirmative action to adopt representation within more multi-ethnic parties. This allows the minority interests broader representation in a larger number of parties and through this a larger ENP. ${ }^{38}$

Finally, the applicability of the state creation to only those BIMAROU states that were affected by partition is now shown to have concentrated vote shares among the major state parties and lowered ENP. The other two specifically Indian features of the analysis, congress vote share and the emergency, affected the two groups in the same way but with differing intensity. The gradual decline of Congress's share of the vote is associated with a greater fragmentation of the vote in both state groupings but with a somewhat larger effect arising in the BIMAROU states. The emergency resulted in a significant reduction of party numbers only in the non-BIMAROU states but concentrated vote shares among the larger competing state parties.

\section{Conclusion}

\footnotetext{
37 The Samajwadi Party and the Bahujan Samaj Party (BSP) have built electoral success by relying on the support of backward classes, particularly in Madhya Pradesh and Uttar Pradesh. The Rashtriya Janata Dal governments in Bihar are additional examples where backward classes and Muslin groups were formed for electoral success. ${ }^{38}$ There is some controversy over whether the political reservation system has increased redistribution in favour of disadvantaged groups and/or government size. Pande (2003) argues that the changes are primarily away from general redistributed programs towards more targeted ones. On the other hand, Zuber $(2015, \mathrm{p} .391)$ argues that "if minority representatives are overwhelmingly members of multi-ethnic parties, as in the case of India, redistribution along party lines only benefits groups targeted with reserved seats inter alia, but not specifically, so no systematic effect is obtained."
} 
In this paper we have used data from 14 Indian states and 183 state elections to test an equilibrium model of political party structure in the spirit of Cox (1997) where the number of parties depends positively on the average voting size of the state's constituencies, the heterogeneity of the state's electorate, state per capita income and a number of constitutional changes and legislative rules designed to affect party numbers.

A comparison of the model's ability to explain the number of political parties with its ability to explain the vote weighted effective number of parties (ENP) is perhaps its greatest insight. While virtually all variables in the model are significant in explaining the absolute number of parties, most of these variables lose significance when used to explain the effective number of parties. This suggests that the factors focused on in this analysis explain the proliferation of smaller sized parties that in turn have little effect on vote concentrations among parties. Stated alternatively, the analysis suggests that the size of electorate, political reservation, literacy, age and income better explain variations in the fringe of active parties than the vote share received among the major contending parties and that the constitutional and other institutional changes to the electoral system since Independence were designed to reduce the proliferation of fringe parties and their rate of turnover. Our results also confirm that the dominance of the Congress party affected the dynamics of party politics particularly by suppressing the emergence of major parties and the imposition of emergency had a temporary disruptive effect on the number of both smaller and larger parties. Studying the impact of political affirmative action on different minority groups over our 14-state grouping, our findings suggest that increase in seat reservation for the heterogenous and geographically dispersed SCs population resulted in the crowding out of a number of smaller sized parties.

While many of the factors influencing party numbers might have seemed to be more relevant in lower income, less developed Indian states, the division of our panel by stage of development did not produce that result. By and large the two groups responded in the same way to the model's explanatory variables, but with varying degrees of intensity. Where the response of the two groups was significantly differently was with respect to changes in the proportion of legislature seats reserved for members of disadvantaged castes and other groups. In the low income BIMAROU states, increases in the proportion of reserved seats decreased both party numbers and ENP, suggesting the crowding out of less specialized parties and the concentration of vote shares on fewer, more ethnic oriented parties. In non- 
BIMAROU states greater affirmative action is associated with more parties and a wider distribution of vote shares among parties. These findings are further complemented by the results of group-specific affirmative actions for SCs and STs in both categories of states. This in turn suggests that in BIMAROU states where the proportion of reserved seats is already high, tying reserved seats to population shares may have gone too far, with the advantages of greater affirmative action offset through the greater targeting of government spending and loss of political competition. 
Table 1

Fixed Effects Poisson Models of the Number and Effective Number of Indian State Parties:

14 Indian States, 1957 - 2018

(absolute value of z-statistic in brackets under coefficient estimate)

\begin{tabular}{|c|c|c|c|c|c|c|c|}
\hline Variable & $\begin{array}{l}\text { Predicted } \\
\text { Sign }\end{array}$ & $\begin{array}{l}\text { Number of } \\
\text { parties } \\
\text { (1) }\end{array}$ & $\begin{array}{c}\text { Number of } \\
\text { parties } \\
(2)\end{array}$ & $\begin{array}{l}\text { Number of } \\
\text { Parties } \\
\text { (3) }\end{array}$ & $\begin{array}{l}\text { Number of } \\
\text { Parties } \\
\text { (4) }\end{array}$ & $\begin{array}{l}\text { Effective Number of } \\
\text { Parties (vote shares) } \\
\text { (5) }\end{array}$ & $\begin{array}{c}\text { Effective Number of } \\
\text { Parties (vote shares) } \\
(6)\end{array}$ \\
\hline constituency density & + & $0.005^{* * *}$ & $0.005^{* * *}$ & $0.005 * * *$ & $0.005 * * *$ & 0.0001 & 0.0001 \\
\hline$\left(1000^{\prime} s\right)$ & & $(4.34)$ & $(4.41)$ & $(4.64)$ & $(4.81)$ & $(0.09)$ & $(0.16)$ \\
\hline \multirow[t]{2}{*}{ seat reservation (AlI) } & - & -1.34 & & -0.882 & & -1.18 & \\
\hline & & $(1.30)$ & & $(1.10)$ & & $(1.06)$ & \\
\hline \multirow[t]{2}{*}{ seat reservation (SC) } & - & & $-2.18 * *$ & & $-2.12 * * *$ & & -0.549 \\
\hline & & & $(2.53)$ & & $(2.87)$ & & $(0.61)$ \\
\hline \multirow[t]{2}{*}{ seat reservation (ST) } & - & & -1.11 & & -0.406 & & -1.59 \\
\hline & & & $(1.06)$ & & $(0.54)$ & & $(1.26)$ \\
\hline \multirow[t]{2}{*}{ old } & - & $-12.9 * * *$ & $-13.2 * * *$ & $-13.1^{* * *}$ & $-13.4^{* * *}$ & 0.016 & 0.021 \\
\hline & & (3.18) & (3.29) & $(3.47)$ & (3.68) & $(0.77)$ & $(0.90)$ \\
\hline \multirow[t]{2}{*}{ literacy } & + & $1.32 * * *$ & $1.11^{* *}$ & $0.803 * * *$ & 0.441 & 0.003 & 0.006 \\
\hline & & (3.38) & $(2.44)$ & $(2.74)$ & $(1.13)$ & $(0.76)$ & $(1.27)$ \\
\hline \multirow[t]{2}{*}{ srgdppc (1000's) } & + & $0.005^{*}$ & 0.005 & $0.006 * *$ & $0.006 * *$ & 0.003 & 0.003 \\
\hline & & $(1.66)$ & $(1.58)$ & $(2.26)$ & $(2.17)$ & $(1.30)$ & $(1.34)$ \\
\hline \multirow[t]{2}{*}{ party recognition } & + & & & $0.469 * * *$ & $0.475 * * *$ & $0.084^{* *}$ & $0.077^{*}$ \\
\hline & & & & $(2.88)$ & $(2.89)$ & $(2.12)$ & $(1.83)$ \\
\hline \multirow[t]{2}{*}{ anti-defection } & + & & & $0.559 * * *$ & $0.584 * * *$ & 0.030 & 0.013 \\
\hline & & & & (3.60) & (3.67) & $(0.55)$ & $(0.24)$ \\
\hline adj_deposit increase & - & & & -0.085 & -0.059 & 0.111 & 0.095 \\
\hline (time diminishing) & & & & $(0.93)$ & $(0.68)$ & $(1.02)$ & $(0.90)$ \\
\hline \multirow[t]{2}{*}{ voting age } & + & & & $1.03 * * *$ & $1.15^{* * *}$ & $-0.495^{* * *}$ & $-0.583^{* * *}$ \\
\hline & & & & $(6.44)$ & (6.17) & $(2.70)$ & (3.02) \\
\hline congress vote & - & & & 0.186 & 0.165 & $-1.19 * * *$ & $-1.18 * * *$ \\
\hline
\end{tabular}




\begin{tabular}{|c|c|c|c|c|c|c|c|}
\hline & & & & $(0.98)$ & $(0.88)$ & (9.79) & (9.93) \\
\hline emergency & - & & & $\begin{array}{c}-0.234^{* * *} \\
(7.20)\end{array}$ & $\begin{array}{c}-0.232 * * * \\
(7.30)\end{array}$ & $\begin{array}{c}-0.229 * * * \\
(5.17)\end{array}$ & $\begin{array}{c}-0.229 * * * \\
(5.15)\end{array}$ \\
\hline state creation & $?$ & & & $\begin{array}{c}0.128^{*} \\
(1.74)\end{array}$ & $\begin{array}{c}0.144^{* *} \\
(2.00)\end{array}$ & $\begin{array}{r}-0.019 \\
(0.30)\end{array}$ & $\begin{array}{r}-0.032 \\
(0.47)\end{array}$ \\
\hline \multicolumn{8}{|l|}{ Statistics } \\
\hline Observations & & 183 & 183 & 183 & 183 & 183 & 183 \\
\hline Log pseudolikelihood & & -474.4 & -473.9 & -459.4 & -458.3 & -263.3 & -263.2 \\
\hline Wald $\chi 2(5,6,12,13)$ & & $6685.3 * * *$ & $6181.7 * * *$ & $518.9 * * *$ & $268.0 * * *$ & $1443.0 * * *$ & $1088.1 * * *$ \\
\hline State fixed effects & & Yes & Yes & Yes & Yes & Yes & Yes \\
\hline Election (cycle) fixed effects & & Yes & Yes & Yes & Yes & Yes & Yes \\
\hline
\end{tabular}

Note: Standard errors are corrected for heteroscedasticity and clustered at the state level. ${ }^{* * *}\left({ }^{* *}\right)\left[{ }^{*}\right]$ significantly different from zero at $1 \%(5 \%)[10 \%]$ 
Table 2

Fixed Effects Poisson Models of Party Entry and Exit:

14 Indian States, 1957 - 2018

(absolute value of z-statistics in brackets below coefficient estimates)

\begin{tabular}{|c|c|c|c|c|c|c|}
\hline Variables & $\begin{array}{l}\text { Parties Entering } \\
\text { (1) }\end{array}$ & $\begin{array}{l}\text { Parties Entering } \\
\text { (2) }\end{array}$ & $\begin{array}{l}\text { Parties Exiting } \\
\text { (3) }\end{array}$ & $\begin{array}{l}\text { Parties Exiting } \\
\text { (4) }\end{array}$ & $\begin{array}{l}\text { Turnover } \\
\text { (5) }\end{array}$ & $\begin{array}{c}\text { Turnover } \\
\text { (6) }\end{array}$ \\
\hline $\mathrm{D}$ (constituency density) & $\begin{array}{c}0.003 * * * \\
(3.93)\end{array}$ & $\begin{array}{c}0.003^{* * *} \\
(3.90)\end{array}$ & $\begin{array}{l}-0.001 \\
(0.70)\end{array}$ & $\begin{array}{l}-0.001 \\
(0.48)\end{array}$ & $\begin{array}{c}0.002^{* * *} \\
(3.34)\end{array}$ & $\begin{array}{c}0.002^{* * *} \\
(3.50)\end{array}$ \\
\hline $\mathrm{D}($ seat reservation (All)) & $\begin{array}{l}-2.81 \\
(1.51)\end{array}$ & & $\begin{array}{l}-2.84 \\
(0.70)\end{array}$ & & $\begin{array}{l}-2.89 \\
(1.27)\end{array}$ & \\
\hline $\mathrm{D}($ seat reservation $(\mathrm{SC})$ ) & & $\begin{array}{l}-0.732 \\
(0.29)\end{array}$ & & $\begin{array}{l}-0.857 \\
(0.23)\end{array}$ & & $\begin{array}{l}-0.843 \\
(0.36)\end{array}$ \\
\hline $\mathrm{D}($ seat reservation $(\mathrm{ST}))$ & & $\begin{array}{c}-3.65^{* *} \\
(2.04)\end{array}$ & & $\begin{array}{l}-3.72 \\
(0.93)\end{array}$ & & $\begin{array}{l}-3.77^{*} \\
(1.70)\end{array}$ \\
\hline$D($ old $)$ & $\begin{array}{c}-27.6 * * * \\
(3.21)\end{array}$ & $\begin{array}{c}-28.8 * * * \\
(3.39)\end{array}$ & $\begin{array}{l}43.4^{* *} \\
(2.21)\end{array}$ & $\begin{array}{r}43.0 * * \\
(2.15)\end{array}$ & $\begin{array}{l}-0.445 \\
(0.04)\end{array}$ & $\begin{array}{l}-1.39 \\
(0.13)\end{array}$ \\
\hline D(literacy) & $\begin{array}{l}-1.23 \\
(0.80)\end{array}$ & $\begin{array}{l}-0.670 \\
(0.45)\end{array}$ & $\begin{array}{l}-2.44 \\
(1.49)\end{array}$ & $\begin{array}{l}-1.45 \\
(0.85)\end{array}$ & $\begin{array}{l}-1.90 \\
(1.38)\end{array}$ & $\begin{array}{l}-1.15 \\
(0.91)\end{array}$ \\
\hline $\begin{array}{l}\text { growth of real income } \\
\text { (over governing tenure) }\end{array}$ & $\begin{array}{l}0.009 \\
(0.59)\end{array}$ & $\begin{array}{l}0.008 \\
(0.54)\end{array}$ & $\begin{array}{r}-0.012 \\
(0.67)\end{array}$ & $\begin{array}{r}-0.015 \\
(0.81)\end{array}$ & $\begin{array}{l}0.003 \\
(0.28)\end{array}$ & $\begin{array}{l}0.001 \\
(0.16)\end{array}$ \\
\hline party recognition & $\begin{array}{c}0.939 * * * \\
(3.39)\end{array}$ & $\begin{array}{c}0.996 * * * \\
(3.51)\end{array}$ & $\begin{array}{c}-2.18^{* * *} \\
(3.77)\end{array}$ & $\begin{array}{c}-2.09 * * * \\
(3.15)\end{array}$ & $\begin{array}{l}0.174 \\
(0.82)\end{array}$ & $\begin{array}{l}0.248 \\
(1.25)\end{array}$ \\
\hline anti-defection & $\begin{array}{c}1.18^{* * *} \\
(4.26)\end{array}$ & $\begin{array}{c}1.18^{* * *} \\
(4.25)\end{array}$ & $\begin{array}{c}-0.734^{* * *} \\
(3.68)\end{array}$ & $\begin{array}{c}-0.75 * * * \\
(3.66)\end{array}$ & $\begin{array}{c}0.466 * * \\
(2.09)\end{array}$ & $\begin{array}{c}0.456^{* *} \\
(2.04)\end{array}$ \\
\hline $\begin{array}{l}\text { adj_deposit increase } \\
\text { (time depreciating) }\end{array}$ & $\begin{array}{l}-0.032 \\
(0.26)\end{array}$ & $\begin{array}{r}-0.043 \\
(0.34)\end{array}$ & $\begin{array}{r}-0.069 \\
(0.70)\end{array}$ & $\begin{array}{l}-0.08 \\
(0.80)\end{array}$ & $\begin{array}{l}-0.042 \\
(0.62)\end{array}$ & $\begin{array}{l}-0.053 \\
(0.73)\end{array}$ \\
\hline voting age & $\begin{array}{c}1.66 * * * \\
(9.24)\end{array}$ & $\begin{array}{c}1.69 * * * \\
(9.42)\end{array}$ & $\begin{array}{c}2.19 * * * \\
(8.49)\end{array}$ & $\begin{array}{c}2.24 * * * \\
(8.12)\end{array}$ & $\begin{array}{c}1.74 * * * \\
(9.87)\end{array}$ & $\begin{array}{c}1.78 * * * \\
(9.73)\end{array}$ \\
\hline
\end{tabular}




\begin{tabular}{|c|c|c|c|c|c|c|}
\hline $\mathrm{D}$ (congress vote) & $\begin{array}{c}-1.11 * * * \\
(3.85)\end{array}$ & $\begin{array}{c}-1.1^{* * *} \\
(3.79)\end{array}$ & $\begin{array}{l}0.025 \\
(0.07)\end{array}$ & $\begin{array}{l}0.047 \\
(0.13)\end{array}$ & $\begin{array}{c}-0.641 * * * \\
(2.68)\end{array}$ & $\begin{array}{c}-0.623 * * * \\
(2.58)\end{array}$ \\
\hline emergency & $\begin{array}{l}0.106 \\
(0.74)\end{array}$ & $\begin{array}{l}0.101 \\
(0.72)\end{array}$ & $\begin{array}{c}1.05^{* * *} \\
(4.41)\end{array}$ & $\begin{array}{c}1.05^{* * *} \\
(4.38)\end{array}$ & $\begin{array}{c}0.559 * * * \\
(4.63)\end{array}$ & $\begin{array}{c}0.555^{* * *} \\
(4.61)\end{array}$ \\
\hline state creation & $\begin{array}{c}0.444^{* *} \\
(2.06) \\
\end{array}$ & $\begin{array}{c}0.439 * * \\
(2.06) \\
\end{array}$ & $\begin{array}{l}0.319 \\
(1.36) \\
\end{array}$ & $\begin{array}{l}0.295 \\
(1.23) \\
\end{array}$ & $\begin{array}{c}0.394^{*} \\
(1.79) \\
\end{array}$ & $\begin{array}{c}0.381^{*} \\
(1.74) \\
\end{array}$ \\
\hline \multicolumn{7}{|l|}{ Statistics } \\
\hline Observations & 169 & 169 & 169 & 169 & 169 & 169 \\
\hline Log pseudolikelihood & -431.6 & -430.4 & -391.2 & -390.1 & -484.3 & -482.0 \\
\hline Wald $\chi^{2}(12,13)$ & $182.2 * * *$ & $2504.7^{* * *}$ & $501.6 * * *$ & $524.3^{* * *}$ & $26879.7^{* * *}$ & $1103.6^{* * *}$ \\
\hline State fixed effects & Yes & Yes & Yes & Yes & Yes & Yes \\
\hline Election (cycle) fixed effects & Yes & Yes & Yes & Yes & Yes & Yes \\
\hline
\end{tabular}


Table 3

Fixed Effects Poisson Models of the Number and Effective Number of Indian State Parties: 14 Indian States, 1957 - 2018 (BIMAROU (5) versus Non-BIMAROU (9) States)

(absolute value of z-statistic in brackets under coefficient estimate)

\begin{tabular}{|c|c|c|c|c|}
\hline \multirow[b]{2}{*}{ Variable } & \multicolumn{2}{|c|}{ Number of Parties } & \multicolumn{2}{|c|}{$\begin{array}{l}\text { Effective Number of Parties } \\
\text { (ENP) }\end{array}$} \\
\hline & $\begin{array}{l}\text { BIMAROU } \\
\text { States } \\
\text { (1) }\end{array}$ & $\begin{array}{c}\text { Non-BIMAROU } \\
\text { States } \\
\text { (2) }\end{array}$ & $\begin{array}{l}\text { BIMAROU } \\
\text { States } \\
\text { (3) }\end{array}$ & $\begin{array}{c}\text { Non-BIMAROU } \\
\text { States } \\
\text { (4) }\end{array}$ \\
\hline constituency density & $0.007^{* * *}$ & $0.004 * * *$ & $-0.002^{* *}$ & $0.001 * *$ \\
\hline$(1000$ 's) & (3.16) & $(11.38)$ & (2.49) & $(2.10)$ \\
\hline \multirow[t]{2}{*}{ seat reservation $(\mathrm{SC})$} & -1.17 & $2.59 *$ & 0.078 & 1.17 \\
\hline & $(0.36)$ & $(1.75)$ & $(0.04)$ & $(1.16)$ \\
\hline \multirow[t]{2}{*}{ seat reservation (ST) } & $-2.01 * *$ & $2.92 * * *$ & $-2.16^{*}$ & 0.721 \\
\hline & $(2.11)$ & $(2.79)$ & $(1.74)$ & $(0.86)$ \\
\hline \multirow[t]{2}{*}{ old } & $-21.9 * * *$ & -5.16 & $-0.077^{*}$ & 0.013 \\
\hline & (2.61) & $(1.36)$ & $(1.83)$ & $(0.54)$ \\
\hline \multirow[t]{2}{*}{ literacy } & $2.14^{* *}$ & 0.811 & 0.005 & 0.007 \\
\hline & $(2.27)$ & (1.41) & $(0.45)$ & (1.43) \\
\hline \multirow[t]{2}{*}{ srgdppc (1000's) } & $0.023 * * *$ & $0.017^{* * *}$ & 0.001 & 0.001 \\
\hline & (3.55) & (5.43) & $(0.04)$ & $(0.44)$ \\
\hline \multirow[t]{2}{*}{ party recognition } & 0.172 & $0.653 * * *$ & $0.076 *$ & $0.105^{* *}$ \\
\hline & $(0.92)$ & $(5.01)$ & $(1.72)$ & $(2.29)$ \\
\hline \multirow[t]{2}{*}{ anti-defection } & $0.609 * * *$ & $0.500 * * *$ & 0.070 & -0.001 \\
\hline & (8.31) & $(2.82)$ & $(0.68)$ & $(0.01)$ \\
\hline adj_deposit increase & -0.145 & -0.061 & $0.159^{*}$ & -0.045 \\
\hline (time diminishing) & $(1.37)$ & $(0.83)$ & $(1.91)$ & $(0.46)$ \\
\hline \multirow[t]{2}{*}{ voting age } & -0.02 & 0.247 & -0.135 & $-0.545^{* *}$ \\
\hline & $(0.07)$ & $(0.81)$ & $(0.34)$ & $(2.05)$ \\
\hline congress vote & -0.281 & -0.28 & $-1.59 * * *$ & $-0.885 * * *$ \\
\hline
\end{tabular}




\begin{tabular}{|c|c|c|c|c|}
\hline \multirow{3}{*}{ emergency } & (0.98) & $(1.21)$ & $(5.50)$ & $(9.07)$ \\
\hline & 0.236 & $-0.204 * * *$ & $-0.443 * * *$ & $-0.203 * * *$ \\
\hline & $(1.26)$ & (7.19) & $(6.48)$ & (3.87) \\
\hline \multirow[t]{2}{*}{ state creation } & 0.027 & & $-0.124^{* *}$ & \\
\hline & $(0.47)$ & & $(2.15)$ & \\
\hline \multicolumn{5}{|l|}{ Statistics } \\
\hline Observations & 67 & 115 & 67 & 115 \\
\hline Log pseudolikelihood & -158.7 & -275.2 & -95.4 & -164.0 \\
\hline Wald $\chi 2(12,13)$ & 11.3 & $746.6^{* * *}$ & $487.8^{* * *}$ & $285.9 * * *$ \\
\hline State fixed effects & Yes & Yes & Yes & Yes \\
\hline Election (cycle) fixed effects & Yes & Yes & Yes & Yes \\
\hline
\end{tabular}




\section{Data Appendix}

Table A1

Descriptive Statistics (14 Indian State averages: 1957-2018)

\begin{tabular}{|c|c|c|c|c|c|c|}
\hline Variable definitions & $\begin{array}{l}\text { Mnemonics used in } \\
\text { tables }\end{array}$ & Obs. & Mean & Std. Dev. & Min & Max \\
\hline $\begin{array}{l}\text { Average number of registered } \\
\text { constituency voters (1000's) }\end{array}$ & $\begin{array}{l}\text { constituency } \\
\text { density }\end{array}$ & 194 & 131.32 & 60.99 & 52.9 & 371.1 \\
\hline Change in constituency's density & $\begin{array}{l}\mathrm{D} \text { (constituency } \\
\text { density) }\end{array}$ & 180 & 13.37 & 16.56 & -19.0 & 174.2 \\
\hline $\begin{array}{l}\text { Number of registered Parties } \\
\text { contesting election }\end{array}$ & Number of parties & 194 & 28.63 & 34.43 & 3 & 302 \\
\hline $\begin{array}{l}\text { Inverse of a Herfindahl index of } \\
\text { party vote shares. }\end{array}$ & $\begin{array}{l}\text { Effective Number of } \\
\text { Parties (vote shares) }\end{array}$ & 194 & 3.95 & 1.12 & 2 & 8 \\
\hline New parties entering state election & Parties Entering & 187 & 16.3 & 23.3 & 0 & 211 \\
\hline Parties exiting following election & Parties Exiting & 187 & 10.0 & 12.7 & 0 & 131 \\
\hline Turnover of political parties & Churning & 187 & 26.3 & 35.0 & 1 & 342 \\
\hline Proportion of all reserved seats & $\begin{array}{l}\text { seat reservation } \\
\text { (All) }\end{array}$ & 194 & 0.223 & 0.076 & 0.09 & 0.4 \\
\hline $\begin{array}{l}\text { Change in the proportion of all } \\
\text { reserved seats }\end{array}$ & $\begin{array}{l}\text { D(seat reservation } \\
\text { (All)) }\end{array}$ & 180 & 0.002 & 0.014 & -0.068 & 0.079 \\
\hline $\begin{array}{l}\text { Proportion of Scheduled Castes (SC) } \\
\text { reserved seats }\end{array}$ & $\begin{array}{l}\text { seat reservation } \\
\text { (SC) }\end{array}$ & 194 & 0.153 & 0.052 & 0.00 & 0.291 \\
\hline $\begin{array}{l}\text { Change in the proportion of SC } \\
\text { reserved seats }\end{array}$ & $\begin{array}{l}\text { D(seat reservation } \\
(\mathrm{SC}) \text { ) }\end{array}$ & 180 & 0.002 & 0.019 & -0.069 & 0.221 \\
\hline $\begin{array}{l}\text { Proportion of Scheduled Tribes (ST) } \\
\text { reserved seats }\end{array}$ & $\begin{array}{l}\text { seat reservation } \\
\text { (ST) }\end{array}$ & 194 & 0.070 & 0.077 & 0.00 & 0.243 \\
\hline $\begin{array}{l}\text { Change in the proportion of ST } \\
\text { reserved seats }\end{array}$ & $\begin{array}{l}\text { D(seat reservation } \\
\text { (ST)) }\end{array}$ & 180 & -0.001 & 0.020 & -0.214 & 0.079 \\
\hline $\begin{array}{l}\text { Herfindahl Index of religious } \\
\text { fragmentation }\end{array}$ & religion frag & 167 & 0.278 & 0.133 & 0.05 & 0.6 \\
\hline $\begin{array}{l}\text { Share of the state population over } \\
60\end{array}$ & old & 183 & 0.070 & 0.014 & 0.05 & 0.134 \\
\hline Change in old population & $\mathrm{D}$ (old) & 169 & 0.003 & 0.003 & -0.005 & 0.014 \\
\hline Literacy rate & literacy & 183 & 0.527 & 0.193 & 0.186 & 0.956 \\
\hline Change in literacy rate & D(literacy) & 169 & 0.037 & 0.030 & -0.14 & 0.109 \\
\hline State real GDP per capita (1000’s) & srgdppc & 183 & 18.79 & 14.6 & 4.36 & 80.09 \\
\hline $\begin{array}{l}\text { Growth rate of real income per } \\
\text { capita over previous government's } \\
\text { tenure }\end{array}$ & $\begin{array}{l}\text { growth of real } \\
\text { income } \\
\text { (over governing } \\
\text { tenure) }\end{array}$ & 181 & 3.13 & 3.26 & -6.42 & 16.43 \\
\hline $\begin{array}{l}\text { Dummy variable: = } 1 \text { for all } \\
\text { elections following 1968; = } 0 \\
\text { otherwise. }\end{array}$ & party recognition & 194 & 0.799 & 0.402 & 0 & 1 \\
\hline $\begin{array}{l}\text { Dummy variable: }=1 \text { for all } \\
\text { elections following } 1985 ;=0 \\
\text { otherwise. }\end{array}$ & anti-defection & 194 & 0.485 & 0.501 & 0 & 1 \\
\hline $\begin{array}{l}\text { Depreciated Dummy variable: }= \\
1^{*} \text { (declining time adjustment) for }\end{array}$ & $\begin{array}{l}\text { adj_deposit } \\
\text { increase } \\
\text { (time depreciating) }\end{array}$ & 194 & 0.257 & 0.369 & 0 & 1 \\
\hline
\end{tabular}


all elections following 1996; $=0$

otherwise.

Vote share of the Congress Party Change in the vote share of the

Congress Party

Dummy variable: $=1$ for the first elections after the lifting of national

$\begin{array}{llllll}\text { congress vote } & 194 & 0.337 & 0.122 & 0.02 & 0.56 \\ \text { D(congress vote) } & 180 & -0.017 & 0.093 & -0.38 & 0.27\end{array}$

$\begin{array}{llllll}\text { emergency } & 194 & 0.072 & 0.259 & 0 & 1\end{array}$

emergency; = 0 otherwise.

Dummy variable: $=1$ for post 2000

state creation

19

0.057

0.232

0

1

elections in three states - Bihar,

Madhya Pradesh, and Uttar

Pradesh; $=0$ otherwise.

Dummy variable $=1$ for years

voting age

194

0.072

.259

0

1 
Table A2

Linear Fixed Effects Models of the Number and Effective Number of Indian State Parties:

14 Indian States, 1957 - 2018

(absolute value of t-statistic in brackets under coefficient estimate)

\begin{tabular}{|c|c|c|c|c|c|}
\hline Variable & $\begin{array}{l}\text { Predicted } \\
\text { Sign }\end{array}$ & $\begin{array}{l}\text { Number of } \\
\text { Parties } \\
\text { (1) }\end{array}$ & $\begin{array}{c}\text { Number of } \\
\text { Parties } \\
\text { (2) }\end{array}$ & $\begin{array}{c}\text { ENP (vote } \\
\text { shares) } \\
\text { (3) }\end{array}$ & $\begin{array}{c}\text { ENP (vote } \\
\text { shares) } \\
\text { (4) }\end{array}$ \\
\hline constituency density (1000's) & + & $\begin{array}{c}0.901^{* * *} \\
(3.58)\end{array}$ & $\begin{array}{c}0.873 * * * \\
(3.50)\end{array}$ & $\begin{array}{l}0.219 \\
(1.04)\end{array}$ & $\begin{array}{l}0.230 \\
(1.11)\end{array}$ \\
\hline seat reservation (All) & - & $\begin{array}{l}-1.14 \\
(1.24)\end{array}$ & & $\begin{array}{l}-0.540 \\
(0.50)\end{array}$ & \\
\hline seat reservation $(\mathrm{SC})$ & - & & $\begin{array}{l}-1.69 \\
(1.70)\end{array}$ & & $\begin{array}{l}-0.330 \\
(0.36)\end{array}$ \\
\hline seat reservation (ST) & - & & $\begin{array}{l}-0.856 \\
(0.88)\end{array}$ & & $\begin{array}{l}-0.640 \\
(0.54)\end{array}$ \\
\hline old & - & $\begin{array}{c}-0.723^{*} \\
(1.84)\end{array}$ & $\begin{array}{c}-0.782^{*} \\
(1.89)\end{array}$ & $\begin{array}{l}-0.015 \\
(0.06)\end{array}$ & $\begin{array}{l}0.008 \\
(0.03)\end{array}$ \\
\hline literacy & + & $\begin{array}{c}0.403 * * * \\
(3.27)\end{array}$ & $\begin{array}{c}0.331^{* * *} \\
(2.32)\end{array}$ & $\begin{array}{l}-0.187 \\
(1.28)\end{array}$ & $\begin{array}{l}-0.160 \\
(0.98)\end{array}$ \\
\hline srgdppc (1000's) & + & $\begin{array}{l}0.172 \\
(1.02)\end{array}$ & $\begin{array}{l}0.178 \\
(1.08)\end{array}$ & $\begin{array}{l}0.247^{*} \\
(1.96)\end{array}$ & $\begin{array}{c}0.245^{*} \\
(1.92)\end{array}$ \\
\hline party recognition & + & $\begin{array}{c}0.388 * * \\
(2.51)\end{array}$ & $\begin{array}{c}0.395 * * \\
(2.54)\end{array}$ & $\begin{array}{l}0.033 \\
(0.56)\end{array}$ & $\begin{array}{l}0.030 \\
(0.51)\end{array}$ \\
\hline anti-defection & + & $\begin{array}{c}0.426 * * \\
(2.56)\end{array}$ & $\begin{array}{c}0.439 * * \\
(2.58)\end{array}$ & $\begin{array}{l}0.058 \\
(0.81)\end{array}$ & $\begin{array}{l}0.053 \\
(0.73)\end{array}$ \\
\hline $\begin{array}{l}\text { adj_deposit increase } \\
\text { (time diminishing) }\end{array}$ & - & $\begin{array}{l}-0.103 \\
(1.06)\end{array}$ & $\begin{array}{l}-0.095 \\
(0.98)\end{array}$ & $\begin{array}{l}0.065 \\
(0.57)\end{array}$ & $\begin{array}{l}0.062 \\
(0.56)\end{array}$ \\
\hline voting age & + & $\begin{array}{c}0.925^{* * *} \\
\quad(3.85)\end{array}$ & $\begin{array}{c}0.987^{* * *} \\
(3.90)\end{array}$ & $\begin{array}{c}-0.559 * * \\
(2.22)\end{array}$ & $\begin{array}{c}-0.583^{* *} \\
(2.24)\end{array}$ \\
\hline congress vote & - & $\begin{array}{c}0.131^{* *} \\
(2.26)\end{array}$ & $\begin{array}{c}0.130 * * \\
(2.32)\end{array}$ & $\begin{array}{c}-0.179 * * * \\
(3.96)\end{array}$ & $\begin{array}{c}-0.179 * * * \\
(4.05)\end{array}$ \\
\hline emergency & - & $\begin{array}{c}-0.247^{* * *} \\
(5.82)\end{array}$ & $\begin{array}{c}-0.249 * * * \\
(5.88)\end{array}$ & $\begin{array}{c}-0.248^{* * *} \\
(6.03)\end{array}$ & $\begin{array}{c}-0.247 * * * \\
(5.89)\end{array}$ \\
\hline state creation & $?$ & $\begin{array}{l}0.179 \\
(1.45) \\
\end{array}$ & $\begin{array}{l}0.193 \\
(1.55) \\
\end{array}$ & $\begin{array}{l}0.038 \\
(0.81) \\
\end{array}$ & $\begin{array}{l}0.032 \\
(0.68) \\
\end{array}$ \\
\hline $\begin{array}{l}\text { Statistics } \\
\text { Observations }\end{array}$ & & & & & \\
\hline $\begin{array}{l}\text { Observations } \\
\text { R-square (overall) }\end{array}$ & & $\begin{array}{c}183 \\
0.850\end{array}$ & $\begin{array}{c}183 \\
0.852\end{array}$ & $\begin{array}{c}183 \\
0.263\end{array}$ & $\begin{array}{c}183 \\
0.273\end{array}$ \\
\hline State fixed effects & & Yes & Yes & Yes & Yes \\
\hline Election (cycle) fixed effects & & Yes & Yes & Yes & Yes \\
\hline
\end{tabular}

Note: Standard errors are corrected for heteroscedasticity and clustered at the state level. ${ }^{* * *}\left({ }^{* *}\right)\left[{ }^{*}\right]$

significantly different from zero at $1 \%(5 \%)[10 \%]$. 
Table A3

Fixed Effects Poisson Models of the Number and Effective Number of Indian State Parties:

14 Indian States, 1957 - 2018 (Election years)

(absolute value of z-statistic in brackets under coefficient estimate)

\begin{tabular}{|c|c|c|c|c|c|}
\hline Variable & $\begin{array}{l}\text { Predicted } \\
\text { Sign }\end{array}$ & $\begin{array}{l}\text { Number of } \\
\text { Parties } \\
\text { (1) }\end{array}$ & $\begin{array}{l}\text { Number of } \\
\text { Parties } \\
\text { (2) }\end{array}$ & $\begin{array}{c}\text { ENP (vote } \\
\text { shares) } \\
\text { (3) }\end{array}$ & $\begin{array}{c}\text { ENP (vote } \\
\text { shares) } \\
(4)\end{array}$ \\
\hline constituency density & + & $0.007 * * *$ & $0.007^{* * *}$ & -0.001 & -0.001 \\
\hline$\left(1000^{\prime} s\right)$ & & (3.76) & (3.91) & $(0.61)$ & $(0.54)$ \\
\hline \multirow[t]{2}{*}{ seat reservation (All) } & - & -1.54 & & -0.675 & \\
\hline & & $(1.42)$ & & $(0.70)$ & \\
\hline \multirow[t]{2}{*}{ seat reservation (SC) } & - & & $-2.65 * *$ & & 0.253 \\
\hline & & & $(2.01)$ & & $(0.32)$ \\
\hline \multirow[t]{2}{*}{ seat reservation (ST) } & - & & -1.12 & & -1.26 \\
\hline & & & $(1.01)$ & & (1.14) \\
\hline \multirow[t]{2}{*}{ old } & - & $-0.084 * *$ & $-0.089 * *$ & 0.011 & 0.019 \\
\hline & & $(2.08)$ & $(2.05)$ & $(0.66)$ & $(0.82)$ \\
\hline \multirow[t]{2}{*}{ literacy } & + & $0.011 * *$ & 0.007 & 0.004 & $0.009 * *$ \\
\hline & & $(2.47)$ & $(1.20)$ & $(1.13)$ & $(2.09)$ \\
\hline \multirow[t]{2}{*}{ srgdppc (1000's) } & + & $0.013^{* * *}$ & $0.013 * * *$ & 0.003 & 0.003 \\
\hline & & (3.52) & (3.49) & $(1.46)$ & $(1.46)$ \\
\hline \multirow[t]{2}{*}{ party recognition } & + & 0.185 & 0.166 & $0.077^{*}$ & $0.096 * *$ \\
\hline & & $(1.41)$ & $(1.20)$ & $(1.68)$ & $(2.29)$ \\
\hline \multirow[t]{2}{*}{ anti-defection } & + & 0.054 & 0.051 & 0.047 & 0.046 \\
\hline & & $(0.43)$ & $(0.42)$ & $(1.23)$ & $(1.18)$ \\
\hline adj_deposit increase & - & $-0.139 * *$ & $-0.129 * *$ & $0.117 * *$ & $0.106 * *$ \\
\hline (time diminishing) & & $(2.25)$ & $(2.22)$ & $(2.19)$ & $(1.95)$ \\
\hline \multirow[t]{2}{*}{ voting age lowering } & + & $0.508 * * *$ & $0.497 * * *$ & -0.051 & -0.044 \\
\hline & & $(4.02)$ & (3.77) & $(0.76)$ & $(0.67)$ \\
\hline \multirow[t]{2}{*}{ congress vote } & - & $0.405^{*}$ & 0.375 & $-1.26 * * *$ & $-1.23 * * *$ \\
\hline & & $(1.75)$ & $(1.58)$ & $(8.64)$ & $(8.60)$ \\
\hline \multirow[t]{2}{*}{ emergency } & - & $-0.118 * *$ & $-0.121 * *$ & $-0.223 * * *$ & $-0.217 * * *$ \\
\hline & & $(2.05)$ & $(2.10)$ & $(2.84)$ & $(2.74)$ \\
\hline \multirow[t]{2}{*}{ state creation } & $?$ & $0.337 * * *$ & $0.357 * * *$ & -0.016 & -0.046 \\
\hline & & $(2.76)$ & (3.06) & $(0.30)$ & $(0.83)$ \\
\hline \multirow[t]{2}{*}{ election years } & $?$ & -0.006 & -0.001 & $-0.010 * *$ & $-0.015 * * *$ \\
\hline & & $(0.67)$ & $(0.07)$ & $(2.11)$ & (3.08) \\
\hline \multicolumn{6}{|l|}{ Statistics } \\
\hline No. of States & & 14 & 14 & 14 & 14 \\
\hline Observations & & 183 & 183 & 183 & 183 \\
\hline Log pseudolikelihood & & -494.6 & -493.7 & -261.7 & -261.5 \\
\hline Wald $\chi^{\wedge} 2(12,13)$ & & $22506.6 * * *$ & $14269.3 * * *$ & $4228.6^{* * *}$ & $4758.5^{* * *}$ \\
\hline State fixed effects & & Yes & Yes & Yes & Yes \\
\hline Election (year) fixed effects & & No & No & No & No \\
\hline
\end{tabular}




\section{References}

Aldrich, J.H. (1995). Why Parties? The Origin and Transformation of Political Parties in America. Chicago, Illinois: The University of Chicago Press.

Amorim-Neto, O. and G.W. Cox (1997). "Electoral institutions, cleavage structures, and the number of parties", American Journal of Political Science 41(1): 149-174.

Auerbach, A.M., and A. Ziegfeld (2020). How do electoral quotas influence political competition? Evidence from municipal, state, and national elections in India. Journal of Politics, 82(1): 397-401.

Berrington, H. (1985). Why some live and most die. International Political Science Review, 6(4): 441-461.

Bhattacharya, K., and S. Mitra (2014). More Can Be Less: Hyper Plurality of Candidates, the Rationality of Electoral Choice, and Need for Electoral Reform in India. India Review 13(1): 15-39.

Bolleyer, N., and E. Bytzek (2017). New party performance after breakthrough: Party origin, building and leadership. Party Politics, 23(6): 772-282.

Brancati, D. (2008). The Origins and Strengths of Regional Parties. British Journal of Political Science, 38(1): 135-159.

Chhibber, P.K., and J.R. Petrocik (1989). The Puzzle of Indian Politics: Social Cleavages and the Indian Party System. British Journal of Political Science, 19(2):191-210.

Chhibber, P.K., and K. Kollman (1998). Party aggregation and the number of parties in India and the United States. American Political Science Review, 92(2): 329-342.

Chhibber, P.K., R.J. Jensenius, and P. Suryanatayn (2014). Party Organization and Party Proliferation in India. Party Politics, 20(4): 489-505.

Chhibber, P.K., and R. Verma (2018). Ideology and Identity: The changing party systems of India Oxford: Oxford University Press.

Chin, A. and N. Prakash (2011). The redistributive effects of political reservation for minorities: Evidence from India. Journal of Development Economics, 96(2): 265-277.

Church, R. (1984). The pattern of state politics in Indira Gandhi's India. In John R Wood (Eds.), State politics in contemporary India: Crisis or continuity? Boulder, Westview.

Clark, W.R., and M. Golder (2006). Rehabilitating Duverger's theory: Testing the mechanical strategic modifying effects of electoral laws. Comparative Political Studies, 39(6): 679708.

Cox, G. (1997). Making Votes Count: Strategic Coordination in the World's Electoral Systems. Cambridge: Cambridge University Press.

Dash, B. B. and J. S. Ferris (2020). Economic performance and electoral volatility: Testing the economic voting hypothesis on Indian states, 1957-2013. Party Politics, forthcoming.

Dash, B.B., J.S. Ferris, and S.L. Winer (2019). The measurement of electoral competition, with application to Indian states. Electoral Studies, 62: 102070.

Dassonneville, R. (2017) "Age and voting", in Arzheimer, K., J. Evans and M.S. Lewis-Beck (eds) The Sage Handbook of Electoral Behaviour Los Angeles: Sage Publications (Chapter 7, 137-158).

Diwakar, R. (2007). Duverger's Law and the size of the Indian party system. Party Politics, 13(5): 539-661.

Duverger, M. (1959). Political Parties: Their Organization and Activity in the Modern State. Second English Revised. London: Methuen \& Co. 
Ferris, J.S., and M. Voia (2020). Political Parties in Canada: What determines their entry, exit and turnover? Party Politics, 26(5): 543-554.

Ferris, J.S., S.L. Winer, and D.E.H. Olmstead (2018). A Dynamic Model of Political Party Equilibrium. Carleton Economic Papers \#18-04.

Forand, J.G., and V. Maheshri (2015). A dynamic Duverger's Law. Public Choice, 165: 285-306.

Ghosh, S. (2016). A quality of growth index: evidence from Indian States. South Asia Economic Journal, 17(1): 133-148.

Grofman, B., S. Bowler, and A. Blais (2009). Duverger's Law of Plurality Voting the logic of party competition in Canada, India, the United Kingdom and the United States. New York: Springer Publishing.

Harmel, R., and J.D. Roberston (1985). Formation and success of new parties: A cross-national analysis. International Political Science Review, 6(4): 501-523.

Harriss, J. (1999). Comparing political regimes across Indian states: A preliminary essay. Economic and Political Weekly, 34(48): 3367-3377.

Hug, S. (2000). Studying the electoral success of new political parties. Party Politics, 6(2): 187197.

Jaffrelot, C. (2012). Caste and political parties in India: Do Indians vote their caste - while casting their vote? In A. Kohli and P. Singh (Eds.), Routledge handbook of Indian politics. Routledge, New York.

Jensenius, F. (2017). Social justice through inclusion: The consequences of electoral quotas in India. Oxford: Oxford University Press.

Jones, M.P. (2004). "Electoral institutions, social cleavages, and candidate competition in presidential elections", Electoral Studies, 23(1): 73-106.

Kaplan, D. and R.L. Venezky (1994). "Literacy and voting behavior: A bivariate probit model with sample selection", Social Science Research 23(4): 350-367.

Kapoor, S., and A. Magesan (2018). Independent candidates and political representation in India. American Political Science Review, 112(3): 678-697.

Kothari, R. (1970). Politics in India. Boston, Little Brown.

Lago, I., and F. Martinez (2011). Why new parties? Party Politics, 17(1): 3-20.

Laroze, D. (2017). Party collapse and new party entry. Party Politics, 25(4): 559-568.

Lucardie, P. (2007). Pristine purity: New political parties in Canada. American Review of Canadian Studies, 39(3): 283-300.

McAllister, I. and D. Muiller (2018). "Early voting, election campaigning and party advantage in Australia" Electoral Studies 52 (1) 103-110.

Meyer, T.M., and B. Miller (2015). The niche party concept and its measurement. Party Politics, 21(2): 259-271.

Milazzo, C., R.G. Moser and E. Scheiner (2018). Social diversity affects the number of parties even under first-past-the-post rules. Comparative Political Studies 51(7); 9387-974.

Mishra, A., and V. Mishra (2018). Is there conditional convergence in the per capita incomes of BIMAROU states in India? Economic Modelling, 70(3): 429-437.

Mori, Y. and T. Kurosaki (2011). Does political reservation affect voting behavior? Empirical evidence from India. Working paper.

Mulligan, C.B., and K.K. Tsui (2015). Political entry, public policies, and the economy. Research in Economics, 69(3): 377-397.

Nikolenyi, C. (2008). Recognition Rules, Party Labels and the Number of Parties in India. Party Politics, 14(2): 213-222. 
Nishikawa, M. (2010). Electoral and party system effects on ruling party durability. Party Politics, 18(5): 633-652.

Ordeshook, P.C. and O.V. Shvetsova (1994). "Ethnic heterogeneity, district magnitude and the number of Parties", American Journal of Political Science, 38(1): 100-123.

Pande, R. (2003). "Can mandated political representation increase policy influence for disadvantaged minorities", American Economic Review 93(4): 1132-1151.

Powell, E.N., and J.S. Tucker (2014). Revisiting electoral volatility in Post-communist countries: new data, new results, and new approaches. British Journal of Political Science, 44(1): 123-147.

Prakash, N., M. Rockmore, and Y. Uppal (2019). Do criminally accused politicians affect economic outcomes? Evidence from India. Journal of Development Economics, 141: (102370).

Riker, W. (1982) The Two-Party System and Duverger's Law: An Essay on the History of Political Science. American Political Science Review, 76: 753-766.

Sethia, A. (2019) Where's the party? Towards a constitutional biography of political parties. Indian Law Review, 3(1): 1-32.

Sikk, A. (2005). How Unstable? Volatility and the Genuinely New Parties in Eastern Europe. European Journal of Political Research, 44(4): 391-412.

Spoon, J., and K.J. West (2015). Alone or together? How party institutions affect party entry in presidential elections in Europe and South America. Party Politics, 21(3): 393-403.

Stockemer, D. and A. Blais (2019). "Voters and Abstainers in National and European Elections", European Review 27(2): 300-315.

Taagepera, R., and B. Grofman (1985). Rethinking Duverger's Law: Predicting the Effective Number of Parties in Plurality and PR Systems - Parties Minus Issues Equals One. European Journal of Political Research, 13(4): 341-352.

Tavits, M. (2006). Party System Change. Party Politics, 12(1): 99-119.

Tavits, M. (2008). Party Systems in the Making: The emergence and success of new parties in New Democracies. British Journal of Political Science, 38(1): 113-133.

Uppal, Y. (2009). The disadvantaged incumbents: estimating anti-incumbency effects in Indian state legislatures. Public Choice, 138(1-2): 9-27.

Winer, S.L., J.S. Ferris, and B.B. Dash (2019). Replication data for The measurement of electoral competition, with application to Indian states. At Scholars Portal Dataverse: https://doi.org/10.5683/SP2/N3GJR4.

Winer, S.L., J.S. Ferris, B.B. Dash, and P. Chakraborty (2020). Political Competitiveness and the Private-Public Structure of Public Expenditure: A model and empirics for the Indian States. International Tax and Public Finance, forthcoming.

Yadav, Y., and S. Palshikar (2003). From hegemony to convergence: party system and electoral politics in the Indian States, 1952 - 2002. Journal of Indian School of Political Economy, 15(1-2): 5-44.

Zuber, C.I. (2015). "Reserved seats, political parties, and minority representation", Ethnopolitics, 14(4): 390-403. 